\title{
Paratesticular Deep "Aggressive" Angiomyxoma
}

National Cancer Institute

\section{Source}

National Cancer Institute. Paratesticular Deep "Aggressive" Angiomyxoma. NCI

Thesaurus. Code C162501.

A locally infiltrating, non-metastasizing angiomyxoma that arises from the paratesticular region. 